\title{
Potential of Mechanization on Output Efficiency and Cost Minimization of Farm Operations in Temperate Fruit Crops of Jammu \& Kashmir, India
}

\section{F.A. Shaheen ${ }^{*}$ and Mudasir Ali}

Sher-e-Kashmir University of Agricultural Sciences and Technology of Kashmir, Shalimar, 190025, Srinagar, India

*Corresponding author: fashaheen@rediffmail.com

Received: $12-07-2020$

Revised: $17-10-2020$

Accepted: 27-11-2020

\section{ABSTRACT}

The level of farm mechanization in Jammu \& Kashmir (J\&K) is very poor badly hampered by terraced, small and irregular fields, undulating topography, lack of skilled manpower, poor facilities of repair and maintenance and manufacture of implements. Due to the wider variation in agro-ecological situations and crops grown in J\&K as compared to rest of the country, the technological breakthroughs of R\&D institutes could not brought benefit in farming as expected. Growing labour scarcity and increasing wage rates in J\&K is further pushing farmers towards the wall. The farmers had to come with their own solutions for farm mechanization problems. It was in this backdrop that the machines were designed and fabricated by the SKUAST-Kashmir to meet the mechanised solutions for some of major fruit crops. The designed machines viz., Motorised Walnut Dehuller, Motorised Almond Dehuller, Manual Almond Dehuller and Apricot Harvester were evaluated at field conditions and found cost effective with high output efficiency. The potential cost minimisations on part of the designed machines were significant (₹ 630 million at J\&K level) thereby, increasing farmers' income by ₹ 2053 per hectare. Farmer groups may own and operate these machines on collective basis and may also provide them on custom hiring basis to other farmers who may not afford to purchase. There lies an ample scope for entrepreneurship development in the mechanised farm service sector, wherein, these newly designed machines may be owned by an entrepreneur to provide them to farmers on custom hiring basis or act as service provider company for harvest and post harvest operations.

Keywords: Farmers' income, economic efficiency, temperate fruits, Jammu and Kashmir

Farm mechanization is regarded as sine-qua-non to reduce the human drudgery and enhance the agricultural productivity. It implies the use of various power sources and improved farm tools and equipment, with a view to reduce the drudgery of the human beings and draught animals, enhance the cropping intensity, precision and timelines of efficiency of utilisation of various crop inputs and reduce the losses at different stages of crop production. The end objective of farm mechanization is to enhance the overall productivity and production with the lowest cost of production besides reducing drudgery of labour.

Jammu and Kashmir is blessed with naturally occurring micro-climatic regions suitable for cultivation of a wide range of agri-horticultural crops with a great potential for development. However, the

How to cite this article: Shaheen, F.A. and Ali, M. (2020). Potential of Mechanization on Output Efficiency and Cost Minimization of Farm Operations in Temperate Fruit Crops of Jammu \& Kashmir, India. Agro Economist - An International Journal, 7(2): 79-88.

Source of Support: None; Conflict of Interest: None 
level of farm mechanisation in J\&K is very poor with respect to mechanical power, efficient implements, water management, land reclamation, renewable energy, harvesting machines and post harvest technology sectors. The farm mechanisation is badly hampered by terraced, small and irregular fields, undulating topography, lack of skilled manpower, poor facilities of repair and maintenance and manufacture of implements. J\&K produces number of crops, fruits and vegetables in different agroclimatic zones and is more specialised in temperate fruit production, where it has a comparative advantage, thereby forming the major share of agricultural GSDP. The availability of farm labour has got further aggravated with implementation of MGNREGA scheme. Growing labour scarcity is met through in-migration of labour class from Bihar, Uttar Pradesh, West Bengal and neighbouring states which are mostly involved in construction sector and some skilled job works. The higher wage rates as compared to rest of the country have made J\&K influxed with non-state labour class. From last several years, the outside labourers are employed even in farm field operations. With a constant increase in the wage rates, the cost of farming operations is escalating bringing lower returns to farmers. Reduction in cost of cultivation is of paramount importance in agriculture. Higher labour inputs and prolonged field operations increase the cost of cultivation. The use of improved machines not only reduces cost of cultivation but improves profitability significantly.

The major temperate fruits of J\&K, such as apple, walnut, almond, apricot etc could have off-set the problem of farm labour scarcity and increase in cost with import of farm mechanisation technology from advanced regions growing same fruits such Europe, China, Australia, USA or Turkey. However, the machines developed by these countries for farm operations are of very big scale feasible for large land holders with plain and well managed farms. Contrary to it, the average holding size in $\mathrm{J} \& \mathrm{~K}$ is 0.66 ha with fragmented land holdings and undulating topography. The Division of Agricultural Engineering of State Agricultural University (SKUAST-Kashmir) started its work in the year 2006 for finding the solutions to develop mechanisation based on local needs. It was in this backdrop that machines were designed and fabricated from time to time during these years to suit local conditions and as per problems identified in the field. Four major machines were made by the Sher-e-Kashmir University of Agricultural Sciences and Technology of Kashmir for harvest and post harvest operations of its major temperate fruit crops. The paper highlights the operational efficiency, viability of mechanised farm operations and the potential of newly designed machines in cost minimization of farm operations and post harvest processing of important temperate fruit crops in the state.

\section{MATERIALS AND METHODS}

The designing and fabrication of farm machines by the institute was prioritized based on the need and demand from the field observations. Accordingly, four machines were designed and fabricated under the Horticulture Technology Mini Mission (HTMM) Project on 'Horticultural mechanization for reducing drudgery and increasing work efficiency in Kashmir valley. Machines thus manufactured under the project were Motorized Walnut Dehuller, Motorized Almond Dehuller, Manual Almond Dehuller and Apricot Harvesting Net/ Catch Net. Machines were fabricated in the workshop of the Division of Agricultural Engineering, SKUAST-Kashmir during 2012 to 2013 period. Machines fabricated under the project were evaluated on field conditions in various districts of the state during the autumn season of 2013 and 2014. In order to examine the economic efficiency of the designed machines, the cost of material used in the fabrication of machines, wages/salaries of the technical staff for fabrication of the said machines, fuel charge and other expenditures were taken into account. Magnitude of cost minimization on part of mechanized harvest and post harvest operations for the fruit crops were compared and discussed with manual operations. To estimate the potential demand of designed machines and overall benefit with respect to cost reduction in the harvest (apricot) and post harvest operations (walnut and almond) of the designed machines, the secondary data on area, production and yield of the fruits (walnut, almond and apricot) were collected from the Directorate of Horticulture, Srinagar, J\&K.

Primary data on the manual output capacity of the labourers for such operation was collected from the farmers during the evaluation of the designed machines at field in order to compare the relative 
operational cost and potential for increasing farmers income through mechanized farm operations.

\section{RESULTS AND DISCUSSION}

The results are discussed under separate headings for each of the designed machine and harvest/post harvest operation for the fruit crop.

\section{Walnut Dehuller}

Walnut is the major dry fruit crop of the state cultivated on an area of 89,339 hectares with a production of 2,66,280 metric tonnes (Directorate of Horticulture - Kashmir, 2016-17). It is grown in temperate zone of the state and contributes more than 95 per cent of total walnut production of country. Most popular varieties of walnut are English (also called Persian) and Black walnut. Walnut has been highly esteemed as a superior desert nut, which requires neither roasting nor salting to enhance its flavour. These are sold both un-shelled and as walnut kernel. It is harvested from October to April in all parts of the world whereas in Kashmir, harvesting season is from August to September. Indian walnut harvesting starts earlier ( 2 months) than any other Northern hemisphere country. It is the second major horticultural cash crop of the state after the apple. Foreign exchange earnings have increased from 115 crores in 2005-06 to 345 crores in 2013-2014 (Statistical Digest, 2015).

Market value of the walnuts is determined on the basis of colour and quality of the shell and kernel which is considerably influenced by the harvest and post harvest procedures. There is a great scope of increasing the production, financial returns and also lowering the post harvest costs by adopting the scientific/technical knowhow instead of the conventional methodology. For best quality and value, walnuts must be harvested as early as possible after maturity (George et al. 1978). Any harvest delay results in increased off grade kernels. Most insect damage or mold can be prevented by timey harvest. Dehulling (removing the green hull from the walnut after harvesting) of walnuts is one of the important post harvest operations, which is very tedious and time consuming resulting in the deterioration of the quality of un-shelled walnuts. Delayed dehulling of walnuts results in blackening, thereby deteriorating its quality and fetches at lower price in the market.
When walnuts are harvested in Kashmir valley, they are traditionally kept under rice/mustard straw or under polythene sheets in the form of a heap, so that the green hull may be loosened or the ethylene in the hull gets released, which makes easy for removing the green hull from the walnuts. Dehulling of walnuts is one of the important post harvest operations and is very tedious, time, labour and energy consuming, besides getting dyed-out the hands of labourers carrying out operation. Farmers are using conventional method of walnut dehulling, which is removing green hull or husk from the walnut with the help of hammers or beating with the stick or using the knife. There was no machine for dehulling of walnuts in the state and furthermore growers do not use any chemicals for the same. Keeping in view the above fact, there was an immediate need of the walnut dehulling machine in the State of Jammu and Kashmir. Machine thus designed and fabricated at SKUAST-Kashmir was tested and demonstrated at farmer's field in different villages of the Kashmir valley.

Walnut dehulling machine consists of two major units, the power source unit and the dehulling unit. Power for the machine is obtained from a petrol start kerosene run $1.03 \mathrm{~kW}$ Honda engine. Power from engine to the main dehulling unit is transmitted using belt and pulley drive. Dehulling unit is one of the most important parts of the machine as dehulling of walnuts takes place in this unit. Dehulling unit consists of two casings and clearance between the stationary and the rotating casing between which the dehulling of walnuts takes place is adjustable depending on the size and shape of walnuts (Table 1 ).

The ease with which walnuts may be dehulled depends upon the nature and maturity of the green hull. Dehulling efficiency is thereby greatly influenced by the number of heaping days. When walnuts are dehulled after harvest without heaping i.e., when the hull is intact with the walnut or the shell, dehulling efficiency was minimum. Variation in hulling efficiency and breakage obtained was studied at different number of heaping days and rpm (rotation per minute) of the machine. Hulling efficiency was found to vary from 89.29 to 93.74 per cent with number of heaping days from 2 to 6 , respectively. Hulling efficiency increases with increase in number of heaping days as well as rpm 
of the machine, however, extended heaping days may deteriorate the quality of walnut in-shell; and breakage increases with respect of rpm of machine due to excess impact of force over walnut kernel at higher rpm. Furthermore to evaluate the performance of machine, the per cent breakage and un-hulled walnut showed decreasing trend with number of heaping days with an $\mathrm{R}^{2}$ value of 99.86 per cent.

\section{Cost Estimates and Relative Economic Efficiency of Mechanized Dehulling}

Specifications and cost analysis for fabrication of machine and operational expenses were estimated and is presented in Table 1.

Fabrication/manufacturing cost of the Motorized Walnut Dehuller was ₹ 27,500 . In order to work out the economic efficiency of the designed machine, the amortised cost was taken into account. Taking salvage value as 10 per cent of the manufacturing cost (₹ 2750) and useful life of 8 years (2000 hours) with an average of 250 working hours per annum, the amortised cost of machine per working hour stands to be ₹ 12.38. The fuel (petrol start - kerosene run) charge per operating hour comes to be ₹ 39. One labour is required to assist the machine operation which comes to be ₹ 50/hour (@ ₹ 400/manday with 8 hours of work). Thus, total operational cost per hour of machine was estimated ₹ 102.43.

Economic efficiency of Motorized Walnut Dehuller vs a vs to manual operation is worked out and presented in Table 2. It was found that manually one labour can dehull 25-32 kgs of walnut per hour on an average, while as, the output capacity of Walnut Dehuller after several trials ranged between 340 - 350

Table 1: Specification and cost analysis of the walnut dehuller

\begin{tabular}{|c|c|}
\hline Specification & Observation \\
\hline Machine & Walnut Dehuller \\
\hline Overall dimensions & $(\mathrm{LXBXH}) 1800 \times 890 \times 1630 \mathrm{~mm}$ \\
\hline Power source & Honda engine, $1.03 \mathrm{~kW}$, GK-100 \\
\hline Transmission unit & $\begin{array}{l}\text { V-Belt and pulley (69B), large pulley } 14 \text { inches, small pulley } \\
2.5 \text { inches }\end{array}$ \\
\hline \multirow[t]{2}{*}{ Dehulling unit } & $\begin{array}{l}\text { Outer cylinder: (MS square bar } 8 \mathrm{~mm} \text { ) diameter } 360 \mathrm{~mm} \text {, } \\
\text { length } 670 \mathrm{~mm} \text {. }\end{array}$ \\
\hline & $\begin{array}{l}\text { Mesh unit: }(35 \mathrm{~mm} \times 30 \mathrm{~mm} \text { ) length } 570 \mathrm{~mm} \text {, diameter } 230 \\
\mathrm{mm} \text {. }\end{array}$ \\
\hline Clearance (between outer cylinder and mesh unit) & $10-45 \mathrm{~mm}$ \\
\hline Feeding unit (tray) & $(1 \times b \times h) 1020 \times 290 \times 760 \mathrm{~mm}$ \\
\hline Fuel type & Petrol start kerosene run \\
\hline \multicolumn{2}{|l|}{ Cost Estimates } \\
\hline Particulars & Figures \\
\hline Fabrication/manufacturing cost & $₹ 27,500$ \\
\hline Salvage/junk value (@ 10\% of Manufacturing cost) & $₹ 2750$ \\
\hline Useful life & 2000 hrs (8 years) \\
\hline Annual working (hrs/year) & 250 \\
\hline Amortized cost of machine per working hour & $₹ 12.38$ \\
\hline $\begin{array}{l}\text { Interest charge per working hour on capital investment } \\
\text { of machine }\end{array}$ & ₹ 1.05 (@14\% interest rate) \\
\hline Fuel charge per working hour of machine & $₹ 39$ \\
\hline Labour charge per hour of operation & $₹ 50$ \\
\hline Total operational cost per hour & $₹ 102.43$ \\
\hline
\end{tabular}


Potential of Mechanization on Output Efficiency and Cost Minimization of Farm Operations...

Table 2: Economic efficiency and potential saving of mechanised walnut dehulling vis-à-vis human labour

\begin{tabular}{|c|c|c|c|}
\hline Contents & Manual & Mechanized & $\begin{array}{l}\text { Difference/Ratio/ } \\
\text { Change (\%) } \\
\text { (Mechanised over Manual) }\end{array}$ \\
\hline Output capacity $\left(\mathrm{kgs} \mathrm{hr}^{-1}\right)$ & $25-32$ & $340-350$ & +994 to $1260 \%$ \\
\hline Operational cost (₹/hr) & 50 & 102.43 & +52.43 \\
\hline Dehulling cost (₹/kg) & $1.57-2$ & $0.30-0.31$ & $-423 \%$ to $-545 \%$ \\
\hline $\begin{array}{l}\text { Operational \& dehulling cost of } \\
\text { machine if run on electricity }\end{array}$ & - & $\begin{array}{l}\text { ₹ } 65.68 / \mathrm{hr} \\
(0.19-0.20 \text { Re. } / \mathrm{kg})\end{array}$ & $\begin{array}{l}+15.68 \\
(-726 \% \text { to } 900 \%)\end{array}$ \\
\hline Walnut dehulling cost for state* (₹) & 418.06 million & 79.88 million & -338.18 million \\
\hline $\begin{array}{l}\text { Labour Requirement } \\
\text { (Potential labour replacement/ } \\
\text { saving) }\end{array}$ & 1.10 million mandays & 95100 mandays & $\begin{array}{l}1.01 \text { million mandays is potential } \\
\text { labour replacement/saving }\end{array}$ \\
\hline $\begin{array}{l}\text { Per machine dehulling capacity / } \\
\text { year }\end{array}$ & - & $86250 \mathrm{kgs}$ & - \\
\hline Walnut dehullers required (No.) & - & 3087 & - \\
\hline Machine-Labour replacement Ratio & - & - & 1: 356 \\
\hline
\end{tabular}

* Total Walnut Production of state for year 2016-17 was 266280 MT.

Kgs/hour. The percentage increase in the output capacity $\left(\mathrm{hr}^{-1}\right)$ ranged between 994 to 1260 per cent. Manual operational cost per worker per hour was ₹ 50 and that of machine ₹ 102.43 / hour. The dehulling cost $\left(\mathrm{kg}^{-1}\right)$ through manual operation was found to range from ₹ 1.57 to $₹ 2$. On the other hand, same was estimated in the range of Re. 0.30 to Re. 0.31 per $\mathrm{kg}$ of mechanised walnut dehulling, thereby, showing cost reduction to the tune of 423 to 545 per cent over the manual operation. The mechanised dehulling cost can further be minimised (Re. $0.19-0.20 / \mathrm{kg}$ ) if the machine is operated on electricity.

Economic gains/ surplus and potential for labour saving on part of mechanised dehulling operation was estimated based on the output efficiency, operational cost and production of fruit crop in the state which is presented under Table 2 . The potential cost reduction on part of dehulling operation with introduction of Walnut Dehuller machine was estimated to the tune of ₹ 338.18 million with 1.01 million mandays of labour saving. This huge sum can turn to profit/savings for the walnut growers/pre-harvest contractors and processors on part of adopting mechanised operation for walnut dehulling. Apart from this, it will also give farmer better returns through quality improvement by dehulling walnuts at proper stage and time through mechanised operation. For current levels of walnut production in the state (266280 MT), there is a requirement of 3087 number of machines with present designed capacity to fully mechanise the dehulling operation of the walnut fruit crop in the state. Machine-labour replacement ratio was found 1: 352, revealing that one walnut dehuller can replace 352 labours for dehulling operation. During the testing and demonstration of machine, walnut growers and people associated with the business were found very much satisfied with the efficiency of the tool and enthusiastic to purchase it.

\section{Almond Dehuller}

Almonds being the second most important nut fruit of the state are grown on an area of 7107 hectares with a production of 6360 MT in 2016-17. Almonds are exported to outside state and make a considerable portion of the earnings from the horticulture sector. Like-wise walnuts, the almonds too have green hull as covering which needs to be dehulled before selling it in market. The almonds are sold both with kernel and without kernel in the market. The dehulling of the fruit forms an important post harvest operation and is carried out manually whereby the green bark is removed one by one with specially designed knives. Manual operation of dehulling almonds is 
even more tedious, time and labour consuming to that of walnut dehulling. In order to minimize the operation time as well as to reduce the drudgery and cost of dehulling, almond dehuller was designed and fabricated. Two types of almond dehuller's were fabricated under the project, viz., motorized almond dehuller and manual almond dehuller.

Specification and cost analysis for fabrication of machine and operational expenses were estimated for the two machines and is presented in Table 3. Fabrication/ manufacturing cost of the Motorized Almond Dehuller was ₹ 17,500 and that of Manual Almond Dehuller as ₹ 6,500. In order to work out the economic efficiency of the designed machines, the amortised cost of machines were estimated. Taking salvage value as ten per cent of the manufacturing cost and useful life of 8 years (2000 hours) with an average of 250 working hours per annum, the amortised cost of machine per working hour stands to be ₹ 7.88 and ₹ 2.93 for motorised and manual almond dehuller's, respectively. Motorised almond dehuller is electricity run with one HP motor and power cost per working hour comes to be ₹ 2.25 (@ ₹3/unit). One labour is required to assist the machine operation which at the rate of ₹ 50 /hour. Thus, total operational cost per hour of machine was estimated ₹ 60.80 and ₹ 53.16 for motorised and manual almond dehuller's, respectively.

Economic efficiency of mechanised operation by employing motorised and manual almond dehuller's vs a vs to manual dehulling operation has been worked out and presented under Table 4.

Table 3: Specifications, Fabrication and operational cost of Motorized and Manual Almond Dehuller

\begin{tabular}{|c|c|c|}
\hline Specification & Observation & \\
\hline Machine & Motorized Almond Dehuller & Manual Almond Dehuller \\
\hline $\begin{array}{l}\text { Overall dimensions } \\
(\mathrm{L} \times \mathrm{B} \times \mathrm{H})\end{array}$ & $1714 \times 630 \times 1360 \mathrm{~mm}$ & $1860 \times 370 \times 1030 \mathrm{~mm}$ \\
\hline Power source & Electric Motor (1HP), CNG Made & Manual (Human energy) \\
\hline Transmission unit & $\begin{array}{l}\text { V-Belt and pulley (69B), large pulley } 14 \text { inches, } \\
\text { small pulley } 2.5 \text { inches }\end{array}$ & \\
\hline Dehulling unit & $\begin{array}{l}\text { Mesh and Concave }(510 \mathrm{~mm}) \\
\text { Hulling cylinder diameter: } 210 \mathrm{~mm}\end{array}$ & Mesh and Concave \\
\hline $\begin{array}{l}\text { Clearance (between outer } \\
\text { cylinder and mesh unit) }\end{array}$ & $10-20 \mathrm{~mm}$ & $10-20 \mathrm{~mm}$ \\
\hline Feeding unit (tray) & $(1 \times b \times h) 600 \times 520 \times 80 \mathrm{~mm}$ & Manual (0.75 - $1 \mathrm{~kg}$ per batch) \\
\hline Economic Analysis & Figures & \\
\hline Fabrication/manufacturing cost & Rs. 17,500 & $₹ 6,500$ \\
\hline $\begin{array}{l}\text { Salvage/junk value (@ 10\% of } \\
\text { Manufacturing cost) }\end{array}$ & $₹ 1750$ & ₹ 650 \\
\hline Useful life & 2000 hrs (8 years) & 2000 hrs (8 years) \\
\hline Annual working hours & 250 & 250 \\
\hline $\begin{array}{l}\text { Amortized cost of machine per } \\
\text { working hour }\end{array}$ & $₹ 7.88$ & $₹ 2.93$ \\
\hline $\begin{array}{l}\text { Interest charge per working } \\
\text { hour on capital investment of } \\
\text { machine }\end{array}$ & Re. 0.67 (@14\% interest rate) & Re. 0.23 (@14\% interest rate) \\
\hline $\begin{array}{l}\text { Electricity charge per working } \\
\text { hour of machine }\end{array}$ & $₹ 2.25$ & - \\
\hline $\begin{array}{l}\text { Labour charge per hour of } \\
\text { operation }\end{array}$ & $₹ 50$ & $₹ 50$ \\
\hline Total operational cost per hour & $₹ 60.80$ & $₹ 53.16$ \\
\hline
\end{tabular}


Potential of Mechanization on Output Efficiency and Cost Minimization of Farm Operations...

Table 4: Economic efficiency and potential saving of mechanised almond dehulling vis-a-vis to human labour

\begin{tabular}{|c|c|c|c|c|c|}
\hline Contents & $\begin{array}{l}\text { Manual/ } \\
\text { Traditional }\end{array}$ & $\begin{array}{l}\text { Motorised } \\
\text { Almond Dehuller }\end{array}$ & $\begin{array}{l}\text { Manual } \\
\text { Almond } \\
\text { Dehuller }\end{array}$ & $\begin{array}{l}\text { Difference/Ratio/ } \\
\text { Change in per cent } \\
\text { (motorised almond } \\
\text { dehuller over } \\
\text { traditional) }\end{array}$ & $\begin{array}{l}\text { Difference/Ratio/ } \\
\text { Change in per cent } \\
\text { (manual almond } \\
\text { dehuller over } \\
\text { traditional) }\end{array}$ \\
\hline $\begin{array}{l}\text { Output capacity } \\
\left(\mathrm{kgs} \mathrm{hr}^{-1}\right)\end{array}$ & $1.5-2$ & $250-300$ & $20-22$ & +14900 to $16566 \%$ & +1000 to $1233 \%$ \\
\hline Operational cost $(₹ / \mathrm{hr})$ & 50 & 60.80 & 53.16 & ₹ 10.80 & $₹ 3.16$ \\
\hline Dehulling cost (₹/kg) & $25-33.34$ & $0.21-0.25$ & $2.42-2.66$ & $-11805 \%$ to $-13236 \%$ & $-933 \%$ to $-1153 \%$ \\
\hline $\begin{array}{l}\text { Almond dehulling cost } \\
\text { for state* (₹) }\end{array}$ & 190.8 million & 1.46 million & 15.9 million & -189.34 million & -174.9 million \\
\hline $\begin{array}{l}\text { Labour Requirement } \\
\text { (Potential labour } \\
\text { replacement/saving) }\end{array}$ & $\begin{array}{l}397500 \\
\text { mandays }\end{array}$ & 26500 mandays & $\begin{array}{l}36136 \\
\text { mandays }\end{array}$ & $\begin{array}{l}371000 \text { mandays } \\
\text { potential labour } \\
\text { replacement/ saving }\end{array}$ & $\begin{array}{l}361364 \text { mandays } \\
\text { potential labour } \\
\text { replacement/ saving }\end{array}$ \\
\hline $\begin{array}{l}\text { Per machine dehulling } \\
\text { capacity / year }\end{array}$ & - & $68750 \mathrm{kgs}$ & $5250 \mathrm{kgs}$ & - & - \\
\hline $\begin{array}{l}\text { Almond dehullers } \\
\text { required (No.) }\end{array}$ & - & 92 & 1211 & - & - \\
\hline $\begin{array}{l}\text { Machine-Labour } \\
\text { Replacement Ratio }\end{array}$ & - & - & - & 1: 4855 & $1: 342$ \\
\hline
\end{tabular}

* Total Almond Production of state for year 2016-17 was 6360 MT.

It was found that manually, one labour can dehull $25-32 \mathrm{kgs}$ of almonds on an average, while as, the output capacity of motorised and manual almond dehuller's ranged between $250 \mathrm{kgs}-300 \mathrm{kgs}$ and 20 kgs - $22 \mathrm{kgs}$ per hour, respectively. There has been a significant percentage increase in the output capacity $\left(\mathrm{hr}^{-1}\right)$ of motorised and manual almond dehuller's over the traditional dehulling operation, however, the manual operated dehuller was found to have very low output capacity $(20-22 \mathrm{kgs} / \mathrm{hr})$ than that of motorised dehuller (250-300 kgs/hr). Dehulling cost $\left(\mathrm{kg}^{-1}\right)$ through manual operation was found to range from $₹ 1.5$ to $₹ 2$, while as, the same were found as Re. 0.21 to 0.25 and ₹ 2.42 to ₹ 2.66 for motorised and manual almond dehullers, respectively. The mechanised operations showed cost reduction $(\mathrm{kg}$ $\left.{ }^{1}\right)$ to the tune of almost $₹ 30$ for motorised almond dehuller over the manual operation and ₹ 27 for manual almond dehuller.

The potential cost reduction on part of mechanised dehulling operation was estimated to the tune of ₹ 189.34 million for motorised and ₹ 174.9 million for manual operated almond dehuller's, respectively. This huge sum becomes a profit opportunity for the almond grower farming community to avail on part of adopting mechanised operation for almond dehulling. For current levels of almond production in the state $(6360 \mathrm{MT})$, there will be a potential demand of 92 motorised and/ or 1211 manual almond dehuller's with present designed machine capacity to fully mechanise the dehulling operation of almond fruit crop in the state. The machine-labour replacement ratio was found 1: 4855 and 1: 342 for motorised and manual operated almond dehuller's, respectively over the traditional/ manual method of dehulling.

\section{Apricot Harvester}

Apricot is the second most important temperate fresh fruit crop of the state grown on an area of 6123 hectares with annual production of 14,501 metric tonnes (2016-17). Apricots are severely restricted in their ecological adaptation. Apricots grown in Kashmir are of central Asian group. Varieties grown in sub-temperate areas of Jammu region are of little or no importance because of their limited commercial value. However, in Ladakh region (cold arid zone), apricots enjoy an outstanding position and district 
Kargil forms the major production hub of the fruit crop. The crop being perishable in nature requires timely harvest without any delay. Scarcity of labour is relatively more in the Ladakh region as compared to rest of the state. At farm level, labour scarcity was found 70 per cent to that of requirement in case of apricot crop (Baba et al. 2011). Problem gets further accentuated during the harvest season and labour wages has also been found high in the region which usually range from ₹ 450 to ₹ 500/manday for farm operations. Harvesting of apricot is either carried through hand picking or by beating the twigs with long sticks and collecting the fallen fruit from the ground. The former method is time consuming and labour expensive, whereas, the latter method makes the fruit bruised and unhygienic with adsorption of dust particles and other impurities, thus reducing significantly its quality, shelf life and market value. Hence, an effective machine to harvest apricots suiting to field conditions was imperative and it was in this backdrop, that the Apricot Harvesting Net and main frame were fabricated under the project whereas, the vibrator/shaker was purchased from the market.

The specifications of the designed and fabricated apricot harvester is given in Table 5 along with its manufacturing cost and operational expenses. The machine basically consists of three parts, i.e., harvesting net of bowl shape with diameter ranging from 6-7 metres; main frame made of iron with three auto wheels for its mobility attached with drawer type collecting basket tray of $540 \times 380 \times 340 \mathrm{~mm}$ $\mathrm{LBH}$; and the vibrator/shaker fitted with telescopic type lance. The harvesting net is mounted on the main frame and rounded at the trunk of tree making a bowl. Then with the help of vibrator/shaker, the branches are gripped with lance and shaked. Within a fraction of 3 - 5 seconds, all the fruits of the branch get detached with shaking and fall on the bowl shaped net which move down with gravity and get collected in the basket fitted at the base of main frame. Once basket gets filled, it is detached, emptied and again put at the base of main frame.

On an average, it takes 7-10 minutes to harvest one tree, however, the effective time will be even less. More time is spent on fitting the net and detaching it from tree to tree. Operation time for harvest was found to vary with the size of tree, topography of land and the inter-spacing of trees in orchards. The time required for harvesting apricot tree by hand, traditional and mechanised methods were 400, 20, and 6 minutes, respectively in Turkey as reported by Erdogan et al. (2003).

Table 5: Specifications, Fabrication cost and operational cost of Apricot Harvester

\begin{tabular}{|c|c|}
\hline Specification & Observation \\
\hline Machine & Apricot Harvester \\
\hline $\begin{array}{l}\text { Diameter of harvesting } \\
\text { net }\end{array}$ & $6-7$ metres bowl shaped \\
\hline Main Frame Dimensions & $\begin{array}{l}(\mathrm{LXBXH}) 2800 \times 660 \times 670 \\
\mathrm{~mm}\end{array}$ \\
\hline Wheels & $\begin{array}{l}\text { Three tyres (auto wheels) Rim } \\
\text { diameter: } 240 \mathrm{~mm}\end{array}$ \\
\hline Power source & Vibrator/Shaker \\
\hline Transmission unit & Lance - telescopic shaft type \\
\hline Collecting tray & $(1 \times b \times h) 540 \times 380 \times 340 \mathrm{~mm}$ \\
\hline Cost Analysis & \\
\hline Particulars & \\
\hline $\begin{array}{l}\text { Fabrication/ } \\
\text { manufacturing cost of } \\
\text { Apricot Harvester }\end{array}$ & ₹ 75,610 \\
\hline $\begin{array}{l}\text { Salvage/junk value (@ } \\
10 \% \text { of Manufacturing } \\
\text { cost) }\end{array}$ & $₹ 7,561$ \\
\hline Useful life & 1800 hrs (9 years) \\
\hline $\begin{array}{l}\text { Annual working (hrs/ } \\
\text { year) }\end{array}$ & $200 \mathrm{hrs}$ \\
\hline $\begin{array}{l}\text { Amortized cost of } \\
\text { machine per working } \\
\text { hour }\end{array}$ & $₹ 37.81$ \\
\hline $\begin{array}{l}\text { Interest charge per } \\
\text { working hour on capital } \\
\text { investment of machine }\end{array}$ & ₹ 2.23 (@14\% interest rate) \\
\hline $\begin{array}{l}\text { Fuel charge per working } \\
\text { hour of machine }\end{array}$ & $₹ 75$ \\
\hline $\begin{array}{l}\text { Labour charge per hour } \\
\text { of operation }\end{array}$ & ₹ 100 \\
\hline $\begin{array}{l}\text { Total operational cost } \\
\left(\mathrm{hr}^{-1}\right)\end{array}$ & $₹ 215$ \\
\hline
\end{tabular}

The fabrication cost per harvester was found ₹ 75,610. Major portion of the fabrication cost is constituted by vibrator/shaker (₹ 60,000), while as, the cost for manufacture of main frame along with harvesting net comes to be $₹ 15,610$. Amortized cost of machine per working hour was found ₹ 37.81 with annual working of 200 hours and useful life of 9 years. 
Potential of Mechanization on Output Efficiency and Cost Minimization of Farm Operations...

Table 6: Economic efficiency and potential saving of mechanised apricot harvesting vis-a-vis manual operation

\begin{tabular}{|c|c|c|c|}
\hline Contents & Traditional/Manual & Mechanised & $\begin{array}{l}\text { Difference/Ratio/ } \\
\text { Change (\%) } \\
\text { (Mechanised over manual) }\end{array}$ \\
\hline Output capacity $\left(\mathrm{kgs} \mathrm{hr}^{-1}\right)$ & $15-17$ & $300-350$ & +1900 to 1958 \\
\hline Harvesting cost (₹/hr) & 50 & 215 & +165 \\
\hline Harvesting cost (₹/kg) & $2.95-3.34$ & $0.72-1.40$ & -140 to 310 \\
\hline 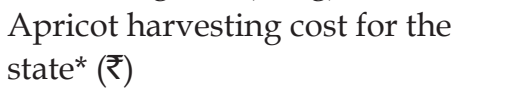 & 43.5 million & 14.5 million & 29 million \\
\hline $\begin{array}{l}\text { Labour Requirement } \\
\text { (Potential labour replacement/ } \\
\text { saving) }\end{array}$ & 1.13 lakh mandays & 5577 mandays & $\begin{array}{l}1.07 \text { lakh mandays is potential } \\
\text { labour replacement/ saving }\end{array}$ \\
\hline $\begin{array}{l}\text { Per machine harvesting capacity } \\
\text { / year }\end{array}$ & - & $65000 \mathrm{kgs}$ & - \\
\hline Apricot Harvesters required (No.) & - & 223 & - \\
\hline $\begin{array}{l}\text { Machine-Labour Replacement } \\
\text { Ratio }\end{array}$ & & & 1: 480 \\
\hline
\end{tabular}

* Total Apricot Production of state for year 2016-17 was 14501 MT.

Harvesting season for the apricot fruit crop hardly lasts for a month. Vibrator/ shaker is petrol run and consumes one litre of fuel per hour on an average. Two persons are required to operate the harvesting machine. The total operational cost works out to be ₹ 215 per hour for the mechanised harvest of apricots.

The economic efficiency and potential saving on part of mechanised harvesting in relation to manual/ traditional harvesting was worked out and is presented in Table 6. Traditionally, one labour harvests 15 to $17 \mathrm{kgs}$ of apricots per hour through hand picking while as it ranged between 300-350 kgs/hour in mechanised operation showing an increase in the output capacity to the tune of 1900 to 1985 per cent over manual operation. Furthermore, harvesting cost gets reduced by 140 to 310 per cent through mechanised to that of manual operation. Similar studies have shown substantial cost reduction due to use of mechanisation methods in groundnut (Govindaraj \& Mishra, 2011) and soybean (Karale et al. 2008) under Indian conditions. Farmers can effectively minimise the operational cost by moving towards mechanised operations. With the present level of apricot fruit production (14501 MT), there is a potential saving worth ₹ 29 million as whole for the state. To fully mechanise the operation for the fruit crop, there is a potential demand of 223 apricot harvesters with present designed capacity. One apricot harvester was found to replace 480 labours in the harvesting operation.

Fabrication cost of apricot harvester is relatively higher than those of other designed machines and may not be affordable for an individual farmer to keep. Apricot farmer groups can own and operate on collective basis and may also be provided on custom hiring services by large farmers who can afford to purchase. A good scope lies for entrepreneurship development in the mechanised farm service sector of the state, wherein, these newly designed machines may be owned by entrepreneurs to provide farmers on custom hiring basis or act as Service Provider Company for harvest and post harvest operations.

\section{CONCLUSION}

Indian agriculture is belatedly engaged in a mechanical revolution, boosting productivity in a sector that has long relied on cheap, surplus labor to tend crops in the world's second most populous country. Job opportunities in factories and services, plus the government's rural job-creation program guaranteeing 100 days of employment a year on public-works projects; have drained the pool of workers from villages. The labor shortage has created a potentially vast opportunity for farm equipment makers. Population dynamics and labor shifts have led to a changing farm landscape. Nobody 
is interested to stand under the sun for 10 hours and work at a farm. As more people will move towards cities and towns in near future, foreseeable scenario predicts more of the small holdings will get combined into larger holdings, making mechanization more attractive and effective. Switch over to mechanized farm operations is growing loud and gaining momentum among the farming community of the Jammu and Kashmir State with the continued increase in wage rates and growing labour scarcity out of competition from off-farm sector. In order to make farming profitable by effectively minimizing the cost of farm operations on one hand and relieving the labour force to a considerable extent for more productive gains on the other hand, farm mechanization has to go a long way in identifying, designing, manufacturing and upscaling of the specially designed machines suitable to local topography and crop structure in consideration with social and environmental factors. The initiative taken in this direction by the R\&D institutes of the state is a welcome step. Researchers and developmental agencies need to further improve upon these technologies and funding should come forth from the donor agencies for dissemination of such technologies under lab to land program on wider scale.

\section{REFERENCES}

Baba, S.H., Wani, M.H., Shaheen, F.A., Zargar, B.A. and Kubrevi, S.S. 2011. Scarcity of agricultural labour in cold-arid Ladakh: extent, implications, backward bending and coping mechanism, Agricultural Economics Research Review, 24(Conference Number): 391-400.

Erdogan, D., Guner, M., Dursun, E. and Gezer, I. 2003. Mechanical harvesting of apricots, Biosystem Engineering, 85(1): 19-28.

George, S.S. and Draper, T.M. 1978. Effect of prolonged drying and harvest delay following ethephon on walnut kernel quality, California Agriculture, 32(6): 12-13.

Govindaraj, G. and Mishra, A.P. 2011. Labour demand and labour-saving options: a case of groundnut crop in India, Agricultural Economics Research Review, 24(Conference Number): 423-428.

Horticulture Data. 2016-17. Directorate of Horticulture Kashmir, Jammu and Kashmir Government, Srinagar, accessed on 13 May, 2017 at http://hortikashmir. gov.in/DATA/AREA \% 20PROD \% 20NET/ Area \% 20 Production \%20\%20\%202016-17.pdf

Karale, D.S., Khambalkar, V.P., Bhende, S.M., Amle, B.S. and Pranali, S.W. 2008. Energy economic of small farming crop production operations, World Journal of Agricultural Sciences, 4(4): 476-482.

Statistical Digest. 2015. Directorate of Economics and Statistics, Planning and Development Department, Srinagar, J\&K. 